\title{
Potency of agricultural wastes in mushroom (Pleurotus sajor-caju) biotechnology for feeding broiler chicks (Arbor acre)
}

\author{
Charles Oluwaseun Adetunji ${ }^{1,2} \cdot$ Isaac Oluseun Adejumo ${ }^{3}$ D
}

Received: 3 November 2017 / Accepted: 21 October 2018 / Published online: 30 October 2018

(c) The Author(s) 2018

\begin{abstract}
Purpose Nigeria produces large quantities of wastes per year, which are underutilised and constitute environmental nuisance. The effect of dietary mycomeat produced from ogi production wastes based on yellow maize using wild and mutant strains of Pleurotus sajor-caju was assessed based on chickens' growth, haematology and histology.

Methods The wastes were air-dried for $72 \mathrm{~h}$. The inoculum was developed by transferring loopful of inoculum into the prepared inoculum medium. Incubation was carried out at $37 \pm 1{ }^{\circ} \mathrm{C} .144$ 1-day-old chicks were used. The trial lasted for 21 days. The chicks were grouped into 4, each containing 361 -day-old chicks. The animals were provided with fresh feed and water ad libitum. Feed intake and body weight were measured weekly, while the calculation of feed conversion ratio (FCR) and weight gain was based on the data obtained.

Results Feed intake was lower for birds fed diets containing ogi production wastes and mycomeat produced from ogi production wastes using a mutant strain of $P$. sajor-caju. No significant differences were observed for body weight gain amongst the treatments. Mycomeat produced from ogi production wastes using a mutant strain of $P$. sajor-caju and ogi production wastes enhanced FCR, while those on wild strain of $P$. sajor-caju did not differ significantly from other treatments.

Conclusion Inclusion of mycomeat in the diet of broiler chicks is considered safe and could promote growth.
\end{abstract}

Keywords Agricultural waste $\cdot$ Food biotechnology $\cdot$ Feed conversion ratio $\cdot$ Mycomeat $\cdot$ Pleurotus sajor-caju

\section{Introduction}

Nigeria, being an agricultural country, produces large quantities of wastes per year. These wastes are underutilised and constitute environmental nuisance as well as a potential challenge to human health (Belewu and Banjo 1999). Agricultural wastes hold significant potentials. Kuppusamy

Isaac Oluseun Adejumo

smogisaac@gmail.com

Charles Oluwaseun Adetunji

charliguitar@yahoo.com

1 Applied Microbiology, Biotechnology and Nanotechnology Laboratory, Department of Biological Sciences, Landmark University, Omu-Aran, Nigeria

2 Laboratory of Genetic Manipulation for Stress Alleviation and Value Addition in Plants, School of Life Sciences, Jawaharlal Nehru University, New Delhi 110067, India

3 Animal Nutrition, Food Security and Food Safety Laboratory, Department of Animal Science, Federal University Gashua, Gashua, Nigeria et al. (2017) observed the need to find effective industrial use for agricultural wastes, being rich in nutrients. Also, the application of compost made from date palm waste has been reported to increase growth rate and yield of Medicago sativa plants (Benabderrahim et al. 2017).

Solid-state fermentation has been identified as a useful technique in food biotechnology, which has gained a lot of interest because of its cost effectiveness. This convenient technology has been employed for the mass production of microorganisms on solid substrates, especially filamentous fungus in a low moisture conditions as well as the easy penetrating nature of the fungal mycelium through the solid substrates (Adetunji and Adejumo 2017; Emilio et al. 2018; Luiz et al. 2018). Solid-state fermentation is an important approach for preventing environmental problems arising from the disposal of agricultural wastes (Devesa-Rey et al. 2011; Oliveira and Duarte 2014). This technology has supported the utilisation of the lignocellulosic wastes as a carbon source for the microorganisms, which are used for the production of various microbial bioproducts, such as feed variety for animals, mycomeat (José et al. 2015; Adejumo 
et al. 2017). Solid-state fermentation has been documented to enhance the nutritional status of the agro-industrial wastes, the biodegradability of agro-industrial wastes and reduction in the concentration of antinutritional factors when used as animal feed (Ajila et al. 2012).

Fermented products made in homes or small-scale industries are consumed as food by family members or used to feed many during social functions. These fermented foods may be produced using cereals, oilseeds, nuts, palm tree sap, legumes, milk, fish, meat, or tubers (Oguntunde 1989; Uzogara et al. 1990). Ogi, a fermented porridge is an important traditional fermented food in Nigeria, which is usually made from Zea mays, Sorghum vulgare or Pennisetum typoideum. Banigo and Muller (1972) described ogi as having sour taste with smooth texture. The uncooked ogi can be made into liquid pap or a solid gel (eko). Ogi is a common popular weaning food as well as food for recuperating patients in Nigeria, which most mothers introduce to their babies at about 6 months of age (Ajanaku et al. 2012).

Mushrooms are traditional foods in Nigeria. They are attractive crop to cultivate in developing countries for many reasons, among which is that they are grown on agricultural wastes, providing substrate materials at low prices or even for free and to conserve our environment by recycling wastes. Not a significant proportion of these wastes have been adequately processed or recycled for use (Barshteyn and Krupodorova 2016). Attempts have been made to convert these wastes to animal feed using mushroom biotechnology. However, previous works on mycomeat focused mainly on the assessment of its nutrient composition (Adejumo et al. 2017; Adetunji and Adejumo 2017). The role of livestock sector in global economy and in combating food insecurity cannot be overemphasised. Poultry, particularly broiler production, has been observed as the fastest growing meat sector in Africa (Meissner et al. 2013; Taha and Hahn 2015). Arbor acre is a class of broiler chickens commonly raised in Nigeria. However, its production is limited by high cost of feed ingredients. Broiler chicks are used in experiments because of the fast growth rate among other factors. The use of agro-wastes to feed poultry, particularly in developing nations could help to reduce cost of production, and thereby, make the animal products more affordable at cheaper cost. This study investigated the effect of dietary mycomeat produced from ogi production wastes based on yellow maize using strains of Pleurotus sajor-caju on growth rate, histology and haematological profile of chicks.

\section{Materials and methods}

The wastes from ogi produced from yellow maize grains used for this study were collected from a seller, being the wastes generated after the extraction of $o g i$, which is the main product. The wastes were air-dried for $72 \mathrm{~h}$ and their proximate composition was carried out according to the procedure of AOAC (2000). Each treatment was done in triplicates. The P. sajor-caju (Fr.) Singer strain LM06 was sourced from NIHORT, southwestern Nigeria.

\section{Inoculum development and UV light-induced mutation}

A sizeable quantity of inoculum was put into a prepared medium and $25 \mathrm{~mL}$ of the isolate was incubated at $37 \pm 1^{\circ} \mathrm{C}$ (Adejumo et al. 2017; Adetunji and Adejumo 2017). The organisms were grown in a freshly prepared potato dextrose agar plate. After the growth of the organisms, mycelia plugs were obtained with cork borer under ultraviolet lamp under the wavelength of $300 \mathrm{~nm}$ at about $0.3 \mathrm{~m}$. Five mycelia plugs were withdrawn during a 30-min interval (Adetunji and Oloke 2013).

\section{Substrate treatments and experimental set-up}

The moisture content of the $o g i$ wastes was maintained at $60 \%$. The waste was divided into three parts, corked and sterilised. Thereafter, the substrates were inoculated with wild and mutant fungi according to the treatments. Treatment 1 contained the agricultural ogi production wastes alone. Treatment 2 contained the wastes and a mutant strain of mushroom. The third treatment contained the wastes and a wild strain of the mushroom (Akintunde and Akintunde 2002; Adetunji and Adejumo 2017; Adejumo et al. 2017).

The substrates having been sterilised were inoculated with $P$. sajor-caju mycelia. A slant was washed per jar and the set-up was incubated at $37{ }^{\circ} \mathrm{C}$ in the dark, which was observed daily until full ramification was noted. The fungi and the substrates were referred to as the mycomeat. Mycomeat refers to the ogi production wastes used as the substrate and the fungi grown on it.

\section{Management of experimental animals and data collection}

The Committee on Animal Ethics, Department of Animal Science, Federal University Gashua, Nigeria approved the feeding trial as well as the experimental protocol. The effect of mycomeat obtained from ogi production wastes using wild and mutant strains of Pleurotus sajor-caju was investigated based on the growth response, ratio of organ to body weight, haematology and liver histology of broiler chicks. Wheat bran was selected as the control because it is commonly used as a feed ingredient in Nigeria while the availability of ogi production wastes informed its choice for the study. One-day-old chicks of Arbor acre strain $(n=144)$ were purchased from a hatchery in Ibadan, Nigeria, and the 
chicks were fed for 21 days. The chicks were grouped into four, each containing 36 1-day-old chicks. Each group represented each treatment, and each treatment was replicated six times. Each replicate had six birds each. The animals were provided with fresh feed and water ad libitum all through the experimental period. Table 1 shows the experimental diet composition. The body weight gain of the experimental animals was calculated by deducting the initial body weight of the birds from the final weight, while the feed conversion ratio was calculated as the ratio of quantity of feed consumed to the body weight gain.

The birds in each group were killed and the livers were excised separately according to the group for histological study. The livers were preserved in universal bottles and fixed in $10 \%$ buffered formalin solution until they were needed for the histological analysis. The tissues were observed and cut into small pieces of about $4 \mathrm{~mm}$. The tissues were processed with tissue processor (Leica TP 1020) and dehydrated by passing them through different reagents. The tissues were eventually placed in wax baths. Having sectioned the tissue appropriately, and the section floated on water bath, the slides through which the sections were picked were labelled, dried and stained accordingly with haematoxylin and eosin (Galighor and Koziff 1976; Avwioro 2010).

Blood was collected into well-labelled specimen tubes (Aiello 1998), and were used for haematological analyses. Packed cell volume (PCV), white blood cell counts (WBC), haemoglobin, neutrophils, lymphocytes and monocytes were determined using standard procedures (Schalm et al. 1975; Campbell 1988).

\section{Experimental design and statistical analysis}

The design of the experiment was a completely randomised design and the data obtained for growth rate, ratio of the weight of organ to the weight of body and haematology indices of the experimental animals were subjected to one-way analysis of variance using SPSS (version 21). Significant means were analysed according to Duncan's multiple range test (Duncan 1955).

Table 1 Gross nutrient composition of experimental diet

\begin{tabular}{|c|c|c|c|c|}
\hline Feed ingredients $(\mathrm{g} / \mathrm{kg})$ & $\begin{array}{l}\text { Control diet (wheat } \\
\text { bran-based) }\end{array}$ & $\begin{array}{l}\text { Ogi production } \\
\text { wastes-based diet }\end{array}$ & $\begin{array}{l}\text { Mycomeat } \text { with a mutant strain of } \\
\text { P. sajor-caju-based diet }\end{array}$ & $\begin{array}{l}\text { Mycomeat with a wild strain } \\
\text { of } P \text {. sajor-caju-based diet }\end{array}$ \\
\hline Yellow maize & 52.00 & 52.00 & 52.00 & 52.00 \\
\hline Soybean meal & 37.00 & 37.00 & 37.00 & 37.00 \\
\hline Palm oil & 1.00 & 1.00 & 1.00 & 1.00 \\
\hline Wheat bran & 6.00 & 0.00 & 0.00 & 6.00 \\
\hline ogi production wastes & 0.00 & 6.00 & 0.00 & 0.00 \\
\hline Mycomeat & 0.00 & 0.00 & 6.00 & 6.00 \\
\hline Premix $^{a}$ & 0.25 & 0.25 & 0.25 & 0.25 \\
\hline Dl-methionine & 0.20 & 0.20 & 0.20 & 0.20 \\
\hline Limestone & 1.50 & 1.50 & 1.50 & 1.50 \\
\hline Di-calcium phosphate & 1.85 & 1.85 & 1.85 & 1.85 \\
\hline Sodium chloride & 0.20 & 0.20 & 0.20 & 0.20 \\
\hline \multicolumn{5}{|l|}{ Analysed nutrients } \\
\hline Protein & 20.08 & 19.89 & 20.13 & 20.10 \\
\hline $\mathrm{ME}(\mathrm{kcal} / \mathrm{kg})$ & 2857.25 & 2856.30 & 2856.30 & 2856.30 \\
\hline Fibre & 4.45 & 4.62 & 4.40 & 4.42 \\
\hline Fat & 4.01 & 4.04 & 4.05 & 4.04 \\
\hline Lysine & 0.75 & 0.76 & 0.77 & 0.76 \\
\hline Methionine & 0.51 & 0.51 & 0.51 & 0.51 \\
\hline Calcium & 1.02 & 1.02 & 1.02 & 1.02 \\
\hline Phosphorus & 0.61 & 0.61 & 0.61 & 0.61 \\
\hline
\end{tabular}

${ }^{\mathrm{a}} 2.5 \mathrm{~kg}$ contains 8,000,000 i.u. vitamin A, 1,600,000 i.u. vitamin D3, 15,000 i.u. vitamin E, $2000 \mathrm{mg}$ vitamin $\mathrm{K}, 3000 \mathrm{mg}$ vitamin B2, $20 \mathrm{~g}$ vitamin C, 20,000 mg niacin, $6000 \mathrm{mg}$ pantothenic acid, $1500 \mathrm{mg}$ vitamin B6, 10,000 mg vitamin B12, $500 \mathrm{mg}$ folic acid, $400 \mathrm{mg}$ biotin, $150,000 \mathrm{mg}$ choline chloride, $100 \mathrm{mg}$ cobalt, $600 \mathrm{mg}$ copper, 10,000 mg iodine, 20,000 mg iron, 90,000 mg manganese, $100 \mathrm{mg}$ selenium, $20,000 \mathrm{mg}$ zinc, $1300 \mathrm{mg}$ antioxidant 
Table 2 Growth performance parameters of broiler chicks fed with control diets and mycomeat produced from ogi production wastes using wild and mutant strain of Pleurotus sajor-caju

\begin{tabular}{llllll}
\hline Parameters & Control diet & Ogi production wastes & $\begin{array}{l}\text { Ogi production } \\
\text { wastes mutant }\end{array}$ & $\begin{array}{l}\text { Ogi production } \\
\text { wastes wild }\end{array}$ & $P$ value \\
\hline Feed intake $(\mathrm{kg})$ & $0.51 \pm 0.01^{\mathrm{a}}$ & $0.38 \pm 0.01^{\mathrm{b}}$ & $0.36 \pm 0.04^{\mathrm{b}}$ & $0.52 \pm 0.02^{\mathrm{a}}$ & 0.004 \\
Initial weight $(\mathrm{kg})$ & $0.15 \pm 0.06^{\mathrm{ns}}$ & $0.14 \pm 0.04^{\mathrm{ns}}$ & $0.14 \pm 0.03^{\mathrm{ns}}$ & $0.15 \pm 0.02^{\mathrm{ns}}$ & 0.897 \\
Final weight $(\mathrm{kg})$ & $0.40 \pm 0.02^{\mathrm{b}}$ & $0.43 \pm 0.03^{\mathrm{ab}}$ & $0.41 \pm 0.01^{\mathrm{ab}}$ & $0.45 \pm 0.03^{\mathrm{a}}$ & 0.124 \\
Weight gain $(\mathrm{kg})$ & $0.25 \pm 0.05^{\mathrm{ns}}$ & $0.29 \pm 0.03^{\mathrm{ns}}$ & $0.26 \pm 0.01^{\mathrm{ns}}$ & $0.30 \pm 0.02^{\mathrm{ns}}$ & 0.236 \\
FCR & $2.11 \pm 0.38^{\mathrm{a}}$ & $1.34 \pm 0.42^{\mathrm{b}}$ & $1.38 \pm 0.10^{\mathrm{b}}$ & $1.75 \pm 0.06^{\mathrm{ab}}$ & 0.038 \\
\hline
\end{tabular}

Values are mean \pm standard deviation, mean with different superscripts within the same row are significantly $(P<0.05)$ different

$n s$ non-significant, $F C R$ feed conversion ratio

\section{Results and discussion}

The growth performance parameters of broiler chicks fed with mycomeat produced from ogi production wastes using strains of Pleurotus sajor-caju are presented in Table 2. Feed intake was lower for birds fed with diets containing ogi production wastes and mycomeat produced from ogi production wastes using a mutant strain of $P$. sajor-caju. There were no significant differences observed for the body weight gain across the treatments. Mycomeat produced from ogi production wastes using a mutant strain of $P$. sajor-caju and ogi production wastes enhanced FCR of the experimental animals, while those on the wild strain of $P$. sajor-caju did not differ significantly from other treatments.

The ratio of the weight of organs and the body weight of chicks fed with mycomeat produced from ogi production wastes using strains of Pleurotus sajor-caju are shown in Table 3. The ratio of dressed weight to body ratio was less for birds fed with diet containing mycomeat produced from ogi production wastes using a mutant strain of $P$. sajor-caju. The ratio head + legs to body weight was, however, higher for birds fed with the diet containing mycomeat produced from ogi production wastes using a mutant strain of $P$. sajor-caju than those on control diet, while those containing mycomeat using a wild strain of $P$. sajor-caju and those on ogi production wastes compared well with the control. The ratio of visceral weight to body weight was lower for birds fed the diet containing mycomeat produced from ogi production wastes using a mutant strain of $P$. sajor-caju than those on control diet, but compared well with other experimental treatments. The values obtained for liver to body weight by the birds on the experimental treatments were statistically similar to the control treatment. The ratio of intestine to body weight did not differ across the treatments. The value obtained for wing weight to body weight for birds fed diet containing mycomeat produced from ogi production wastes using a mutant strain of $P$. sajor-caju was statistically similar to the other treatments. Diets containing mycomeat obtained lower gizzard weight to body weight ratio.

The haematological indices of the chicks fed with mycomeat produced from ogi production wastes strains of Pleurotus sajor-caju are presented in Table 4. Mycomeatbased diets compared with the control diet for packed cell volume and red blood cell counts. The values obtained for white blood cell counts for the experimental diets did not differ significantly from the control group. However, birds on mycomeat with the mutant strain of P. sajor-caju obtained a lesser value than the diet with the wild strain of $P$. sajorcaju. The mycomeat produced with a mutant strain of $P$.
Table 3 Organ weights to body weight ratios of broiler chicks fed with control diets and mycomeat produced from ogi production wastes using wild and mutant strains of Pleurotus sajor-caju

\begin{tabular}{llllll}
\hline Parameters & Control diet & Ogi production wastes & $\begin{array}{l}\text { Ogi production } \\
\text { wastes mutant }\end{array}$ & $\begin{array}{l}\text { Ogi production } \\
\text { wastes wild }\end{array}$ & $P$ value \\
\hline Dressed weight & $0.67 \pm 0.02^{\mathrm{ab}}$ & $0.70 \pm 0.05^{\mathrm{a}}$ & $0.56 \pm 0.05^{\mathrm{c}}$ & $0.60 \pm 0.04^{\mathrm{bc}}$ & 0.012 \\
Head+legs & $0.17 \pm 0.07^{\mathrm{b}}$ & $0.20 \pm 0.01^{\mathrm{b}}$ & $0.33 \pm 0.03^{\mathrm{a}}$ & $0.13 \pm 0.03^{\mathrm{b}}$ & 0.002 \\
Visceral & $0.27 \pm 0.01^{\mathrm{a}}$ & $0.25 \pm 0.05^{\mathrm{ab}}$ & $0.17 \pm 0.04^{\mathrm{b}}$ & $0.18 \pm 0.08^{\mathrm{ab}}$ & 0.079 \\
Liver & $0.07 \pm 0.02^{\mathrm{a}}$ & $0.06 \pm 0.01^{\mathrm{ab}}$ & $0.06 \pm 0.02^{\mathrm{ab}}$ & $0.03 \pm 0.01^{\mathrm{b}}$ & 0.086 \\
Intestine & $0.13 \pm 0.03^{\mathrm{ns}}$ & $0.13 \pm 0.02^{\mathrm{ns}}$ & $0.07 \pm 0.01^{\mathrm{ns}}$ & $0.10 \pm 0.01^{\mathrm{ns}}$ & 0.006 \\
Wings & $0.13 \pm 0.03^{\mathrm{a}}$ & $0.128 \pm 0.03^{\mathrm{a}}$ & $0.11 \pm 0.01^{\mathrm{ab}}$ & $0.081 \pm 0.01^{\mathrm{b}}$ & 0.086 \\
Gizzard & $0.13 \pm 0.02^{\mathrm{a}}$ & $0.13 \pm 0.02^{\mathrm{a}}$ & $0.06 \pm 0.03^{\mathrm{b}}$ & $0.07 \pm 0.01^{\mathrm{b}}$ & 0.005 \\
\hline
\end{tabular}

Values are mean \pm standard deviation, mean with different superscripts within the same row are significantly $(P<0.05)$ different

$n s$ non-significant 
Table 4 Haematological parameters of broiler chicks fed with control diets and mycomeat produced from ogi production wastes using wild and mutant strains of Pleurotus sajor-caju

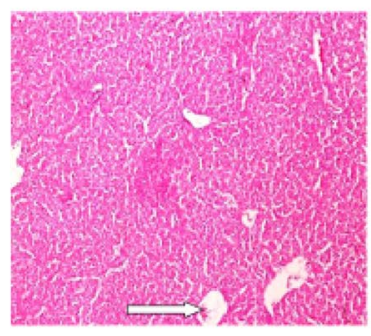

$\mathrm{X} 100$

\begin{tabular}{lccccc}
\hline Parameters & Control diet & $\begin{array}{c}\text { Ogi production } \\
\text { wastes mutant }\end{array}$ & $\begin{array}{c}\text { Ogi production } \\
\text { wastes control }\end{array}$ & $\begin{array}{l}\text { Ogi production } \\
\text { wastes wild }\end{array}$ & $P$ value \\
\hline PCV $(\%)$ & $31.1 \pm 2.01^{\mathrm{a}}$ & $30.8 \pm 0.2^{\mathrm{a}}$ & $27.2 \pm 1.91^{\mathrm{b}}$ & $32.0 \pm 1.1^{\mathrm{a}}$ & 0.001 \\
$\mathrm{WBC}\left(\times 10^{3} \mathrm{~mm}^{3}\right)$ & $2.90 \pm 0.20^{\mathrm{ab}}$ & $2.5 \pm 0.5^{\mathrm{b}}$ & $2.7 \pm 0.3^{\mathrm{ab}}$ & $3.2 \pm 0.5^{\mathrm{a}}$ & 0.102 \\
$\mathrm{RBC}\left(\times 10^{6} \mathrm{~mm}^{3}\right)$ & $3.27 \pm 0.30^{\mathrm{a}}$ & $3.27 \pm 0.3^{\mathrm{a}}$ & $1.72 \pm 0.22^{\mathrm{b}}$ & $3.61 \pm 0.19^{\mathrm{a}}$ & 0.001 \\
Neutrophils $(\%)$ & $30.0 \pm 2.05^{\mathrm{a}}$ & $35.0 \pm 2.16^{\mathrm{a}}$ & $18.0 \pm 0.9^{\mathrm{b}}$ & $14.0 \pm 2.0^{\mathrm{b}}$ & 0.001 \\
Lymphocytes $(\%)$ & $70.0 \pm 3.02^{\mathrm{b}}$ & $65.0 \pm 3.1^{\mathrm{b}}$ & $80.0 \pm 4.1^{\mathrm{a}}$ & $80.0 \pm 3.1^{\mathrm{a}}$ & 0.001 \\
Monocytes $(\%)$ & $0.00 \pm 0.00^{\mathrm{c}}$ & $0.0 \pm 0.0^{\mathrm{c}}$ & $2.0 \pm 0.1^{\mathrm{b}}$ & $6.0 \pm 0.4^{\mathrm{a}}$ & 0.001 \\
Haemoglobin $(\mathrm{mg} / \mathrm{dl})$ & $10.3 \pm 0.03^{\mathrm{b}}$ & $10.21 \pm 0.73^{\mathrm{b}}$ & $9.01 \pm 0.2^{\mathrm{c}}$ & $11.0 \pm 0.3^{\mathrm{a}}$ & 0.001 \\
\hline
\end{tabular}

Values are mean \pm standard deviation, mean with different superscripts within the same row are significantly $(P<0.05)$ different

$n s$ non-significant, $P C V$ packed cell volume, $W B C$ white blood cell counts, $R B C$ red blood cell counts

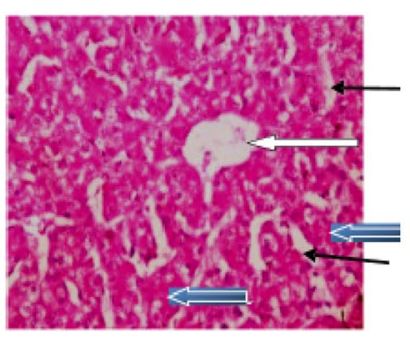

$\mathrm{X} 400$
Photomictograph of a liver showing normal central venules and normal portal tracts (white arrow), the morphology of the hepatocytes appear normal (blue arrow), the sinusoids appear normal and not infiltrated (slender arrow). No pathological lesion was observed.

Figure a: Liver photomicrographs of chicken fed with control diet

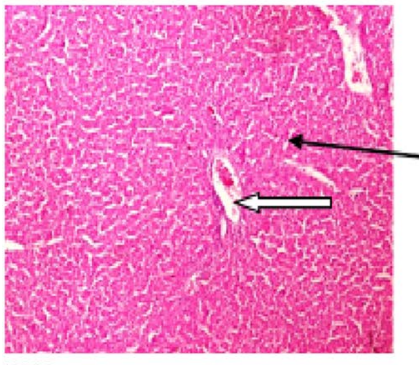

$\times 100$

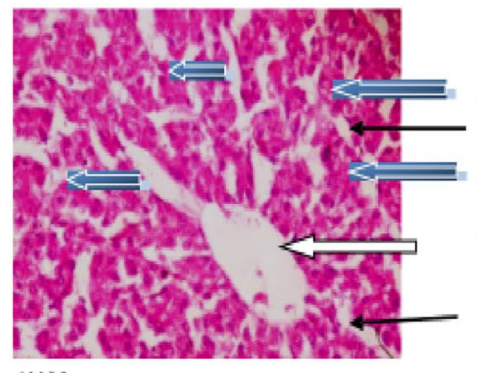

$\times 400$
Photomicrograph of a liver showing normal architecture and as well as normal central venules and nomal portal tracts with no congestion (white artows). The morphology of the hepatocytes appeared normal (blue arrows) and the sinusoids appeared nommal without infiltration (slender arrow). No pathological lesion was observed.

Figure c: Liver photomicrographs of chicken fed with diet containing mycomeat from yellow maize wastes using wild strain of $P$, sajor caju

Fig. 1 a Liver photomicrographs of chicken fed with control diet. b Liver photomicrographs of chicken fed with diet containing yellow maize wastes. $\mathbf{c}$ Liver photomicrographs of chicken fed with diet containing mycomeat from yellow maize wastes using wild strain of $P$.

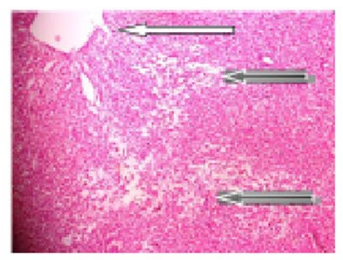

$\mathrm{x} 100$

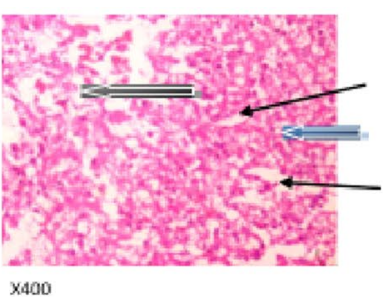

Photomicrograph of a liver showing nomal central venules and normal portal tracts (white arrows). The morphology of the hepatocytes showed severe fat infiltration into the hepatocytes cytoplasm (blue arrow). The sinusoids appeared normal and not infiltrated (slender atrows).

Figure b: Liver photomicrographs of chicken fed with diet
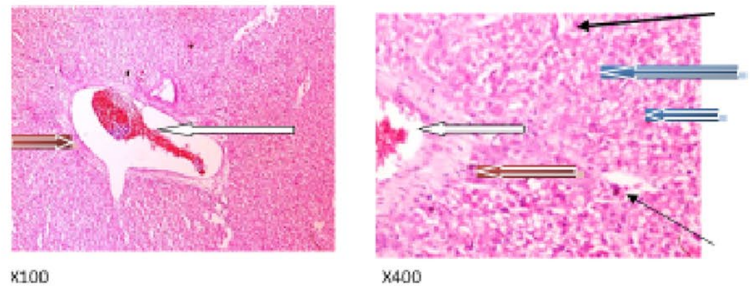

Photomicrograph of a liver showing very mild congestion of the portal vein (white arrow) and mildly increased connective tissues around the portal tract (black arrow). A focal area of wery mild lymphocytes aggregate was observed (black arrow). The morphology of the hepatocytes showed moderate to severe fat infiltration into the hepatocytes cytoplasm with vesicular nuclei (red arrow). The sinusoids appeared nomal and not infiltrated (slender arrow).

Figure d: Liver photomicrographs of chicken fed with diet containing mycomeat from yellow maize wastes using mutant strain of $P$. sajor caju containing yellow maize wastes sajor-caju. d Liver photomicrographs of chicken fed with diet containing mycomeat from yellow maize wastes using mutant strain of $P$. sajor-caju 
sajor-caju compared well with the control diet for packed cell volume, white blood cell counts, red blood cell counts, neutrophils, lymphocytes, monocytes and haemoglobin.

Figure 1a-d shows the liver photomicrographs of broiler chicks fed with the control diet, and diets containing ogi production wastes and mycomeat produced from ogi production wastes using strains of $P$. sajor-caju. The photomicrograph of liver section excised from the broiler chicks fed with the control diet showed a normal architecture. The photomicrograph of a liver section from broiler chicks fed with the diet containing ogi production wastes showed normal central venules and normal portal tracts. The architecture was poor, and the morphology of the hepatocytes showed severe fat infiltration into the hepatocytes' cytoplasms. However, the sinusoids appeared normal without infiltration.

Those birds fed with mycomeat from a wild strain of $P$. sajor-caju showed normal architecture as well as normal central venules and normal portal tracts, which showed no congestion. The morphology of the hepatocytes and the sinusoids appeared normal without any infiltration. No pathological lesion was observed. The photomicrographs of the livers from broiler chicks fed with mycomeat produced with a mutant strain of $P$. sajor-caju reflected that the portal tracts showed very mild congestion of the portal vein as well as mildly increased connective tissues around the portal tract. The morphology of the hepatocytes showed moderate to severe fat infiltration into the hepatocytes' cytoplasms with vesicular nuclei. However, the sinusoids appeared normal and not infiltrated.

Mycomeat from ogi production wastes with a wild strain of $P$. sajor-caju seems to enhance the liver architecture of the experimental chicks. The sinusoids of all the livers from the experimental chicks observed appeared normal and not infiltrated. Hence, it could be said that they pose no serious threat to the livers' function. However, it is recommended that further studies should be carried out to ensure the safety of mycomeat produced from ogi production wastes on liver's functions and architecture of broiler chicks.

The bodyweight gain and feed efficiency have been linked, as being genetically correlated (Mendonça and Michelan 2001). Broiler chicks are usually selected for improved feed conversion ratio and rapid growth rate. It was reported that the growth of Pekin ducks was affected by feed consumption (Wen et al. 2015). Choct (2009) opined that broiler chickens fed with $3 \mathrm{~kg}$ of feed within 5 weeks can reach $2 \mathrm{~kg}$ body weight. Feed consumption has been identified to influence the rapid growth rate of broiler chickens rather than increased nutrient digestibility (Klasing 2007). Feed quality is suggested to have a very significant impact on broiler growth (Jafarnejad et al. 2010) amongst others, such as nutrient density and environmental temperature. However, it has been noted that excessive feed intake may not enhance the growth rate, but could depress digestibility of the nutrient (Wen et al. 2015). Puvanendran et al. (2003) noted that a high-feed intake could reduce digestibility, absorption of nutrients as well increase the rate at which food materials pass through the gastro-intestinal tract.

Feedstuffs, labour, equipment, environment, production methods and measurement accuracy have been observed as factors that may improve feed conversion ratio as well as depress weight gain (Patrício 2007). Patricio et al. (2012) reported the following values for average daily body weight gain, FCR and FCR adjusted for $1.7 \times 10^{3}$ and $2.0 \times 10^{3}$ of broiler as $2326.77 \pm 110,51.16 \pm 2.48,1.968 \pm 0.06$, $1.789 \pm 0.08$ and $1.875 \pm 0.08$, respectively. The FCR for broilers raised in Sudan for 42 days with different feed forms has been reported to be 2.12, 2.22 and 2.27 for broiler chickens fed with mash, mash + pellet and pellet feed, respectively (Ahmed and Abbas 2013). Patricio et al. (2012) noted that the highest FCR was observed in 1992 where $2.116 \mathrm{~kg}$ feed was needed to raise the body weight of broiler by $1 \mathrm{~kg}$, but an annual decline was observed, thereafter, resulting in the need of $1.84 \mathrm{~kg}$ of feed to raise body weight by $1 \mathrm{~kg}$ in 2009. Decline in FCR implies that less quantities of feed will be required, which is an important indicator towards cost effectiveness, since feed accounts for a larger proportion of the total cost of producing live broilers. The inclusion of mycomeat in broiler ration is recommended as a positive and cost-effective way of managing agricultural wastes, which are allowed to decay or are burnt indiscriminately in public places in some developing countries, thereby resulting in environmental pollution.

Analysis of blood parameters is regarded as an important tool for investigating the health status, physiological, pathological and nutritional status of animals (Afolabi et al. 2010). The values obtained for haematological parameters in the present study were within the range reported in the literature. Therefore, it suggests that dietary inclusion of mycomeat in the diet of broiler chicks is safe for consumption. The following values had been reported for RBC $(\times 10 / \mu \mathrm{L}), \mathrm{PCV}(\%)$ and $\mathrm{Hb}(\mathrm{g} / \mathrm{dl}): 2.35 \pm 0.12,29.4 \pm 0.15$, $13.06 \pm 0.32 ; 2.39 \pm 0.09,30.7 \pm 0.86,13.19 \pm 0.25$; $2.85 \pm 0.12,32.71 \pm 0.94,13.95 \pm 0.22$ and $2.59 \pm 0.05$, $31.28 \pm 0.16,13.62 \pm 0.16$ for Arbor acre broilers for days 14, 21, 42 and mean values, respectively (Talebi et al. 2005). Similar values for PCV and haemoglobin concentrations were also reported for finisher broiler chickens fed with acidified blood meal-based diets by Ogunwole et al. (2017). Also, the values observed in the present study were within the range reported (Tehrani et al. 2012; Ologhobo and Adejumo 2015; Ologhobo et al. 2017) for broiler chickens. It has been suggested that the blood composition and performance are related (Isaac et al. 2013).

No inflammation of liver or other organ was observed in the present study. Also, none of the organs experienced colour change. However, the hepatocytes of the livers from 
ogi production wastes and a mutant strain of P. sajor-caju were fat infiltrated. The infiltration is referred to as steatosis. There could be alcohol-induced steatosis and non-alcoholrelated steatosis. It is not unlikely that the grains from which the wastes were collected were partially aflatoxin infested. This could not be ascertained because we did not have access to the grains before they were processed and the wastes were not subjected to aflatoxin test.

Steatosis is used to describe the abnormal accumulation of fatty acids or monoglycerides, diglycerides or triglycerides in hepatocytes (Mavrelis et al. 1983). Plasma-free fatty acids attached to lipoprotein particles in the normal lipid metabolism are transported to the liver where they are either stored or oxidised. Abnormal storage of lipids may lead to hepatocellular damage. Abnormal accumulation of fatty acids concentration has been linked with pathologic liver fat accumulation (Bradbury 2006). Also, it has been noted that steatosis (alcohol-induced) may trigger a series of pathophysiologic disorders. It has, however, been reported that most patients with simple steatosis do not progress to cirrhosis and its complications, such as liver failure and hepatocellular carcinoma (Younossi 2008). Yip and Burt (2006) also noted that the presence of steatosis is not essential for the diagnosis of liver disease. It may even be reversed after the predisposing lifestyle (alcohol consumption) has stopped (Yip and Burt 2006).

The presence of microvesicular liver steatosis has been associated with feed restriction for 35 days in broiler chicks and it was not accompanied with the development of fibrosis of the liver tissue (Makovicky et al. 2011). It was reported in another study that the livers of active chickens raised with no clinical signs of disease revealed many lesions, ranging from parenchymatous, vacuolar and fatty degeneration. The variations were more pronounced from day 10 , which included bile ductule proliferation, hypertrophy of endothelium cells in arteries and hypertrophy of the smooth muscle in arteries.

Aflatoxin-fed quails have been reported to show liver fatty changes, necrosis, bile duct hyperplasia and aggregation of lymphocyte (Ibrahim 2013). The intensity of the changes was a function of the aflatoxin level in the diet. Also, Kumar and Balachandran (2009) in another study observed macrovesicular fatty degeneration, vacuolar degeneration and ballooning degeneration of the hepatocytes of the livers of chickens fed with aflatoxin, which completely altered the architecture of the liver, and the regenerating hepatocytes were arranged in acinar or ductular patterns.

Also, the body condition of animals has been observed to play important roles in liver metabolism. The body condition of dairy cows was reported to affect liver metabolism (Reid and Collins 1980). Depression of feed intake and energy deficiency have been reported to cause a rapid loss of body mass and the accumulation of intracellular fat in the liver (Pivko et al. 2016). Pivko et al. (2016) also observed an accumulation of lipoproteins and lipid droplets in the hepatocytes of cows and attributed the observation to moderate severe steatosis. In the present study, the histological observations of the livers were not accompanied with change in organ colour or size. Hence, the observations may not be linked with the feeding of the experimental diet.

When considering the vulnerability of poultry birds to hepatic steatosis, it is worth noting that liver plays important roles in the fatty acid synthesis (Leveille et al. 1975) unlike in mammals where major synthesis takes place in the adipose tissue. Dietary carbohydrates, fats and adipose tissue depots contribute significantly to the lipids found in the liver. Dietary defects, toxic substances and physiological disturbances are some of the factors that may cause the hepatic accumulation of fat (Butler 1976). A high carbohydrate consumption may also be responsible for an increase in the lipid content of the liver, which may result from feeding a high-energy diet by force-feeding or ad libitum (Wolford and Polin 1974). It is noted that hepatic steatosis may also occur as a result of inadequate production of phospholipids (Butler 1976).

The utilisation of random mutagenesis for the improvement of strain has been discovered leading to increase in yield and hyper production of biological important bioproducts. During this study, UV light was employed for strain improvement of the wild strain of $P$. sajor-caju (Krisztina et al. 2008; Adetunji and Adejumo 2017). During this study, it may be said that the mutant strain exhibited a high level of colonisation and increased in yield, which might be attributed to the fact that mutation might have enhanced the sporulation rates and increased the rapid release of hydrolytic enzymes involved in the biodegradation of lignocellulosic materials in ogi production wastes (Brunner et al. 2005; Juhasz et al. 2005; Fowler et al. 2002). It may be inferred from the findings of this study that the strains used in this study can be improved for the large-scale production of the mycomeat, especially at industrial level using ogi production wastes. It could also help in selection of starting biological agents and in mutation programme, particularly for industrial production (Zaldivar et al. 2001; Krisztina et al. 2008).

\section{Conclusion}

The findings from this study revealed that ogi production wastes based on yellow maize have the potential of being used as animal feed ingredient that could help reduce the cost of production of animal products as well as the cost expended on the disposal of agricultural wastes, thereby minimising various health and environmental hazards. Studies with longer duration may shed more light on this. 
Open Access This article is distributed under the terms of the Creative Commons Attribution 4.0 International License (http://creativeco mmons.org/licenses/by/4.0/), which permits unrestricted use, distribution, and reproduction in any medium, provided you give appropriate credit to the original author(s) and the source, provide a link to the Creative Commons license, and indicate if changes were made.

\section{References}

Adejumo IO, Adetunji CO, Adeyemi OS (2017) Influence of UV light exposure on mineral composition and biomass production of mycomeat produced from different agricultural substrates. J Agric Sci 62:51-59. https://doi.org/10.2298/JAS1701051A

Adetunji CO, Adejumo IO (2017) Nutritional assessment of mycomeat produced from different agricultural substrates using wild and mutant strains from Pleurotus sajor-caju during solid state fermentation. Anim Feed Sci Techno 224:14-19. https://doi. org/10.1016/j.anifeedsci.2016.12.004

Adetunji CO, Oloke JK (2013) Efficacy of freshly prepared pesta granular formulations from the multi-combination of wild and mutant strain of Lasiodiplodia pseudotheobromae and Pseudomonas aeruginosa. Albanian J Agric Sci 12:555-563

Afolabi KD, Akinsoyinu AO, Olajide R, Akinleye SB (2010) Haematological parameters of the Nigerian local grower chickens fed varying dietary levels of palm kernel cake. Proceedings of 35th Annual Conference of Nigerian Society of Animal Production, p 247

Ahmed ME, Abbas TE (2013) The effect of feeding pellets versus mash on performance and carcass characteristics of broiler chicks. Bull Env Pharmaco Life Sci 2:31-34

Aiello SE (1998) The merck veterinary manual, 8th edn. Merck \& Co., Inc., Whitehouse Station, p 2305

Ajanaku KO, Ajanaku CO, Edobor-Osoh A, Nwinyi OC (2012) Nutritive value of sorghum ogi fortified with groundnut seed (Arachis hypogaea L.). Am J Food Tech 7:82-88. https://doi.org/10.3923/ ajft.2012.82.88

Ajila CM, Brar SK, Verma M, Tyagi RD, Godbout S, Valéro JR (2012) Bio-processing of agro-byproducts to animal feed. Crit Rev Biotechnol 32:1-19. https://doi.org/10.3109/07388551.2012.659172

Akintunde TY, Akintunde BO (2002) Development of models for predicting the yield and quality of soymilk. J Food Techno Afr 7:55-58. https://doi.org/10.4314/jfta.v7i2.19245

AOAC (2000) Official Methods of Analysis. 17th Ed. Analytical Chemist s Inc. Arlington Virginia 22201 USA

Avwioro OG (2010) Histochemistry and tissue pathology, principle and techniques. Claverianum Press, Nigeria

Banigo EOI, Muller HG (1972) Carboxylic acid patterns in ogi fermentation. J Sci Food Agric 23:101-111. https://doi.org/10.1002/ jsfa.2740230113

Barshteyn VY, Krupodorova TA (2016) Utilization of agro-industrial waste by higher mushrooms: modern view and trends. J Microbiol Biotechnol Food Sci 6:563-577. https://doi.org/10.15414/jmbfs .2016.5.6.563-577

Belewu MA, Banjo NO (1999) Biodelignification of rice husk and sorghum stover by edible mushroom (Pleurotus sajor-caju). Trop J Anim Sci 1(2):137-142. https://doi.org/10.4314/tjas.v1i2.49605

Benabderrahim MA, Elfalleh W, Belayadi H, Haddad M (2017) Effect of date palm waste compost on forage alfalfa growth, yield, seed yield and minerals uptake. Int J Recycl Org Waste Agricult. https ://doi.org/10.1007/s40093-017-0182-6

Bradbury MW (2006) Lipid metabolism and liver inflammation I. Hepatic fatty acid uptake: possible role in steatosis. Am J Physiol Gastrointest Liver Physiol 290:G194-G198. https://doi. org/10.1152/ajpgi.00413.2005
Brunner K, Zeilinger S, Ciliento R, Woo SL, Lorito M, Kubicek CP et al (2005) Improvement of the fungal biocontrol agent Trichoderma atroviride to enhance both antagonism and induction of plant systemic disease resistance. Appl Environ Microbiol 71:3959-3965. https://doi.org/10.1128/AEM.71.7.3959-3965.2005

Butler EJ (1976) Fatty liver diseases in the domestic fowl-a review. Avian Pathology 5:1-14. https://doi.org/10.1080/0307945760 8418164)

Campbell TW (1988) Avian Haematology and Cytology. USA, Iowa State Univ. Press

Choct M (2009) Managing gut health through nutrition. Br Poult Sci 50:9-15. https://doi.org/10.1080/00071660802538632

Devesa-Rey R, Vecino X, Varela-Alende JL, Barral MT, Cruz JM, Moldes AB (2011) Valorization of winery waste vs. the costs of not recycling. Waste Manage 31:2327-2335. https://doi. org/10.1016/j.wasman.2011.06.001

Duncan DB (1955) Multiple range and multiple F-test. Biometric $11: 1-42$

Emilio R, Marta P, Ángeles MS (2018) Solid-state fermentation for food applications. Curr Adv Solid State Ferment. https://doi. org/10.1016/B978-0-444-63990-5.00015-3

Fowler T, Barnett C, Shoemaker S (to Genencor International, Inc.) (2002) Improved saccharification of cellulose by cloning and amplification of the betaglucosidase gene of Trichoderma reesei. European Patent EP 1225227, July 24

Galighor AE, Koziff EN (1976) Essentials of practical microtechnique, 2nd edn. Lea and Febriger, New York

Ibrahim QQ (2013) Histopathological study of quails liver experimentally induced by aflatoxin. Bas J Vet Res 12:116-127

Isaac LJ, Abah G, Akpan B, Ekaette IU (2013) Haematological properties of different breeds and sexes of rabbits. In: Proceedings of the 18th Annual Conference of Animal Science Association of Nigeria, pp 24-27

Jafarnejad S, Farkhoy M, Sadegh M, Bahonar AR (2010) Effect of crumble-pellet and mash diets with different levels of dietary protein and energy on the performance of broilers at the end of the third week. Vet Med Inter. http://www.hindawi.com/journ als/vmi/2010/328123/. http://dx.doi.org/10.4061/2010/328123 (Article 328123)

Juhasz T, Szengyel Z, Reczey K, Siika-Aho M, Viikari L (2005) Characterization of cellulases and hemicellulases produced by Trichoderma reesei on various carbon sources. Process Biochem 40:3519-3525. https://doi.org/10.1016/j.procbio.2005.03.057

Klasing KC (2007) Nutrition and the immune system. Br Poult Sci 48:525-537. https://doi.org/10.1080/00071660701671336

Krisztina K, La'szlo’ M, George S, Christian PK, Mats G, Guido Z (2008) Trichoderma atroviride mutants with enhanced production of cellulase and -glucosidase on pretreated willow. EMT 43:48-55

Kumar R, Balachandran C (2009) Histopathological changes in broiler chickens fed aflatoxin and cyclopiazonic acid. Veterinarski Arhiv 79:31-40

Kuppusamy S, Venkateswarlu K, Megharaj M (2017) Evaluation of nineteen food wastes for essential and toxic elements. Int J Recycl Org Waste Agricult. https://doi.org/10.1007/s40093-017-0178-2

Leveille GA, Romsos DR, Yeh YY, O'Hea EK (1975) Lipid biosynthesis in the chick. A consideration of site of synthesis, influence of diet and possible regulatory mechanisms. Poult Sci 54:1075-1093

Luiz AJL, Francisco MDV, Gilberto VMP, Susan GK, Adriane BPM, Eduardo SFC, Lucas B, Carlos RS (2018) Solid-state fermentation for the production of mushrooms. Curr Adv Solid-State Ferment. https://doi.org/10.1016/B978-0-444-63990-5.00014-1

Makovicky P, Dudova M, Tumova E, Rajmon R, Vodkova Z (2011) Experimental study of non-alcoholic fatty liver disease (NAFLD) on a model of starving chickens: is generalization of steatosis 
accompanied by fibrosis of the liver tissue? Pathol Res Pract 207:151-155. https://doi.org/10.1016/j.prp.2010.12.002

Mavrelis PG, Ammon HV, Gleysteen JJ, Komorowski RA, Charaf UK (1983) Hepatic free fatty acids in alcoholic liver disease and morbid obesity. Hepatology 3:226-231. https://doi.org/10.1002/ hep. 1840030215

Meissner HH, Scholtz MM, Palmer AR (2013) Sustainability of the South African livestock sector towards 2050 part 1: worth and impact of the sector. South Afr J Anim Sci 43(3):282-297. https ://doi.org/10.4314/sajas.v43i3.5

Mendonça ES, Michelan T. Formação $e$ características das linhagens atuais de frango. Anais $d a 19^{\mathrm{a}}$ Conferência Apinco de Ciência $e$ Tecnologia Avícolas (2001). Facta, Campinas, pp 23-35

Oguntunde AO (1989) Traditional convenience foods from major Nigerian cereal grains. Niger Food J 7:58-66

Ogunwole OA, Abu OA, Adedeji BS, Jemiseye FO, Ojelade AYP, Tewe OO (2017) Haematology and serum indices of finisher broiler chickens fed acidified blood meal-based diets. JABB 11:23941081. https://doi.org/10.9734/JABB/2017/30227

Oliveira M, Duarte E (2014) Integrated approach to winery waste: waste generation and data consolidation. Front Environ Sci Eng. https://doi.org/10.1007/s11783-014-0693-6

Ologhobo AD, Adejumo IO (2015) Haematological response and serum biochemical profile of broiler finishers fed with oxytetracycline and stonebreaker (Phyllanthus amarus) leaf meal. BBJ 7:51-56. https://doi.org/10.9734/BBJ/2015/10304

Ologhobo AD, Akangbe E, Adejumo IO, Ere R, Agboola B (2017) Haematological and histological evaluation of african mistletoe (Viscum albium) leaf meal as feed additive for broilers. ARRB 15:1-7. https://doi.org/10.9734/ARRB/2017/35042

Patricio IS (2007) Dezessete anos da avicultura brasileira. Revista Avicultura Brasileira 5:35-37

Patricio IS, Mendes AA, Ramos AA, Pereira DF (2012) Overview on the performance of Brazilian broilers (1990-2009). Bra J Poult Sci 14:233-304. https://doi.org/10.1590/S1516-635X2012000400001

Pivko J, Makovický P, Makarevich A, Sirotkin A, Makovický P, Kubovičová E (2016) Pathological alterations in hepatocytes of dairy cows with a tendency to emaciation and fattening. Folia Veterinaria 60:53-60. https://doi.org/10.1515/FV-2016-0019

Puvanendran V, Boyce DL, Brown J (2003) Food ration requirements of 0+ yellowtail flounder Limanda ferruginea (Storer) juveniles. Aquaculture 220:459-475. https://doi.org/10.1016/S0044 -8486(02)00620-8

Reid IM, Collins RA (1980) The pathology of postparturient fatty liver in high-yielding dairy cows. Invest. Cell Pathol 3:237-249

Salgado José Manuel, Abrunhosa Luís, Venâncio Armando, Domínguez José Manuel, Belo Isabel (2015) Enhancing the bioconversion of winery and olive mill waste mixtures into lignocellulolytic enzymes and animal feed by Aspergillus uvarum using a packed-bed bioreactor. J Agric Food Chem 63:9306-9314. https://doi.org/10.1021/acs.jafc.5b02131

Schalm OW, Jain NC, Caroll EJ (1975) Veterinary haematology, 3rd edn. Lea and Fabiger, Philadelphia, pp 15-218

Taha FA, Hahn WF (2015) Factors driving south african poultry and meat imports 1 . International food and agribusiness management review, 18 special issue A, pp 165-182

Talebi A, Asri-Rezaei S, Rozeh-Chai R, Sahraei R (2005) Comparative studies on haematological values of broiler strains (ross, cobb, arbor-acres and arian). Int J Poult Sci 4:573-579. https://doi. org/10.3923/ijps.2005.573.579

Tehrani A, Javanbakht J, Askari S, Aghamohammad HM, Solati A, Golami S, Akbari H (2012) Haematological studies on broiler chickens fed with different levels of Artemia Urmiana. J Biotechnol Biomater. http://dx.doi.org/10.4172/2155-952X.1000138

Uzogara SG, Agu LN, Uzogara EO (1990) A review of traditional fermented foods, condiments and beverages in Nigeria: their benefits and possible problems. Ecol Food Nutr 24:267-288. https://doi. org/10.1080/03670244.1990.9991145

Wen Z, Xie M, Fouad A, Tang J, Maqbool U, Huang W, Hou S (2015) The effect of feed consumption levels on growth performance and apparent digestibility of nutrients in White Pekin ducks. J Appl Anim Res 43:112-117. https://doi.org/10.1080/09712 119.2014.928624

Wolford JH, Polin D (1974) Induced fatty liver-hemorrhagic syndrome (FLHS) and accumulation of hepatic lipid in force-fed laying chickens. Poult Sci 53:65-74. https://doi.org/10.3382/ps.0530065

Yip WW, Burt AD (2006) Alcoholic liver disease. Semin Diagn Pathol 23:149-160. https://doi.org/10.1053/j.semdp.2006.11.002

Younossi ZM (2008) Review article: current management of nonalcoholic fatty liver disease and non-alcoholic steatohepatitis. Aliment Pharmaco Ther 28:2-12. https://doi.org/10.111 1/j.1365-2036.2008.03710.x

Zaldivar M, Velasquez JC, Contreras I, Perez LM (2001) Trichoderma aureoviride 7-121, a mutant with enhanced production of lytic enzymes: its potential use in waste cellulose degradation and/or biocontrol. EJB Electron J Biotechnol. http://www.ejb.org/conte nt/vol4/issue3/full/7, https://doi.org/10.2225/vol4-issue3-fullt ext-7

Publisher's Note Springer Nature remains neutral with regard to jurisdictional claims in published maps and institutional affiliations. 